\title{
DEVELOPMENT OF COLLAPSED GLACIAL TOPOGRAPHY IN THE ADAMS INLET AREA, ALASKA, U.S.A.
}

\author{
By GARRY D. MCKENZIE \\ (Institute of Polar Studies and Department of Geology and Mineralogy, Ohio State University, Columbus, \\ Ohio 43210, U.S.A.) \\ and ROBERT G. GOODWIN
}

(Department of Geology, University of Nebraska-Lincoln, Lincoln, Nebraska 68588, U.S.A.)

ABSTRACT. Modes of formation and rates of collapse have been determined for kame terraces and a fan delta in the Adams Inlet area, Alaska. The hummocky and trenched surface of the kame terrace develops by mass-wasting processes caused by differential melting of buried ice. The dry channels in the collapsed part of the terrace are formed by melt water during stagnant-ice bursts. Measurements over a period of 17 years indicate that terrace back-wasting averages $4.3 \mathrm{~m} \mathrm{a}^{-1}$. The fan delta is forming near sea-level by streams that derive part of their load from the kame terrace. The fan delta seaward of the retreating kame terrace is undergoing partial collapse to produce kettles ringed by concentric fractures. Vegetation, now as much as $5 \mathrm{~m}$ below high tide, suggests a fan-delta collapse rate of about $0.5 \mathrm{~m} \mathrm{a}^{-1}$.

\section{INTRODUCTION}

Rapid deglaciation of parts of Glacier Bay National Park and Preserve in south-eastern Alaska, combined with a long record of observations, has provided an ideal setting for the investigation of collapsed glacial topography. About 100 years ago, Adams Inlet (Fig. 1) was covered by $400 \mathrm{~m}$ of ice; 250 years ago, at the time of maximum ice

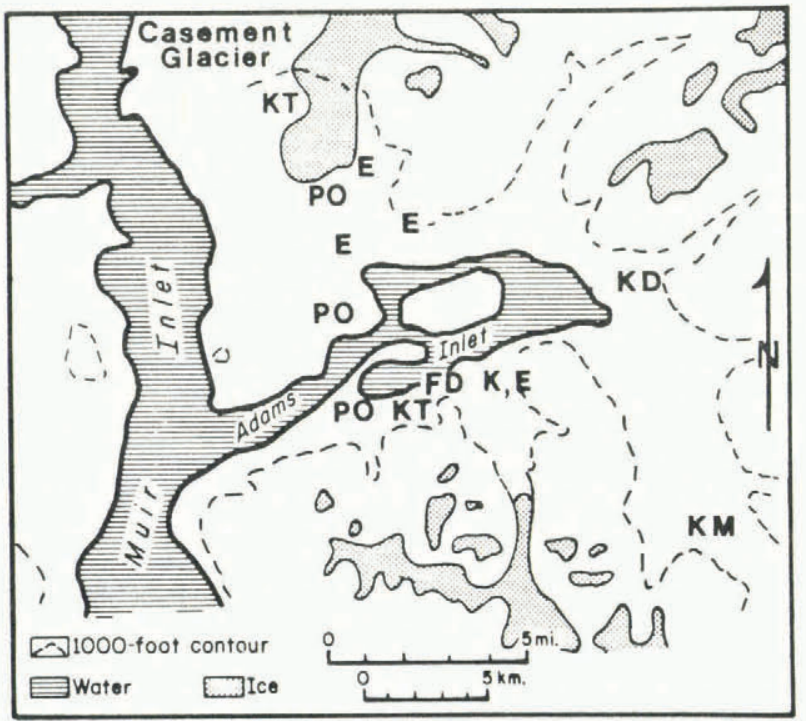

Fig. 1. Collapsed and collapsing ice-contact deposits in Adams Inlet: esker (E), kame terrace (KT), kame moraine $(K M)$, kame delta (KD), fan delta (FD), and pitted outwash (PO). During deglaciation, retreating ice fronts developed on the west, at the junction with Muir Inlet, and on the south-east, north of KM. thickness, it was covered by $760 \mathrm{~m}$ of ice (Reid, 1892). Today it is ice-free, except for buried ice blocks that continue to melt and modify the landscape. Land forms associated with this wasting ice include: eskers, kame terraces, kame moraines, kame deltas, fan deltas, and pitted outwash (Fig. 1). This paper focuses on the development of two deposits, a kame terrace and a fan delta, that have been studied in the field over periods of 17 and 2 years, respectively.

The regional geology has been described by MacKevett and others (1971). Details of the glacial history of the area have been given by Goldthwait (1963), Goldthwait and others (1966), Haselton (1966), and McKenzie and Goldthwait (1971). Maps and photographic records useful in reconstructing development of these glacial land forms are found mainly in Field (1947, 1964), McKenzie (1970), and Reid (1892, 1896).

The climate of the area, with weather observations for two summers, has been described elsewhere (McKenzie, 1970). Mean temperatures for July 1966 and 1967 were $12.2^{\circ} \mathrm{C}$; the January mean is expected to be between $-3.4^{\circ}$ and $-4.8^{\circ} \mathrm{C}$, the recorded means for nearby Gustavus and Haines, respectively.

\section{SETTING AND FORMATION OF ICE-CONTACT STRATIFIED DEPOSITS}

Ice-contact stratified deposits, those glacio-fluvial deposits that have formed in contact with glacier ice, are well developed in Adams Inlet for geographical and other reasons. During the Neoglacial, Adams Inlet Glacier formed in a basin floored by outwash and inwash now preserved as a peninsula and an island (Fig. 1) above tide level. This basin is bordered on the south and east by $1300 \mathrm{~m}$ high mountains separated by valleys which were filled with tributary valley glaciers that flowed into Adams Inlet Glacier. One outlet for Adams Inlet Glacier was a valley glacier to the south-east, which contained an ice-marginal lake during deglaciation. To the north, Casement Glacier dominated the ice-flow pattern toward the inlet. Retreat of Casement Glacier and formation of pro-glacial deposits on the north side of the inlet have been described by Price (1966) and Goodwin and Brookner (1985). On the west, Adams Inlet Glacier joined Muir Glacier. Retreat of Muir Glacier tide-water terminus exposed Adams Inlet Glacier to tidal action, which promoted rapid deglaciation in Adams Inlet.

As the ice in Adams Inlet receded on two fronts, one in the west and one in the south-east (see Fig. 1), and lowered at about $7.9 \mathrm{~m} \mathrm{a}^{-1}$ (Field, 1947), ice-marginal outwash from tributary glaciers and inwash from mountain run-off deposited debris on the margins of Adams Inlet Glacier. This debris was derived from till plastered on valley walls and covering the thick glacio-lacustrine and 
glacio-fluvial deposits that floor the margins of Adams Inlet. Gully erosion of these deposits continues today, building deltas and fan deltas into the inlet. Adams Inlet will eventually become a lake and finally will be filled with outwash and inwash gravels, as it was 1700 years ago (McKenzie and Goldthwait, 1971).

With continued melting of the buried ice, the ice-contact deposits undergo collapse, during which fluvially produced sedimentary structures are destroyed. The rate of collapse depends upon the thickness of cover and the transfer of heat to the ice by conduction and percolating precipitation (McKenzie, 1969). The resulting topography will reflect the distribution of buried ice. If most of the area is underlain by ice, a hummocky topography results; if only parts of the deposit are ice-cored, then individual depressions or kettles will be formed. This kame terrace is undergoing complete collapse while the fan delta is partially collapsing.

\section{KAME-TERRACE DEVELOPMENT}

The mechanism of kame-terrace development in Adams Inlet has been described by McKenzie (1969). Formation of these collapsing deposits is reviewed here and changes that have occurred over the past 15 years are described. A kame terrace begins as an ice-marginal fluvial deposit. As ice retreats, this deposit, which may rest partially on buried ice, is left on the valley wall above the glacier. The kame terrace studied was apparently formed in this manner on the south side of Adams Inlet. This process was noted in Glacier Bay as early as 1890 by Muir (1915). Although a small part of the debris considered here might be a lateral moraine as shown in a map by Reid (1892), and another part of the deposit might best be termed a "kame fan" because alluvial fan processes appear to have dominated deposition there, the general term kame terrace is used.

Aerial photographs taken in 1929 (Field, 1947) show that glacier ice on the south side of the inlet was about $60 \mathrm{~m}$ above sea-level at that time, considerably lower than the $300 \mathrm{~m}$ of Reid in 1892. Debris-covered ice is shown in the area of the kame terrace in 1946 (Field, 1947)

Observations in 1966 and 1967 revealed that these deposits were undergoing collapse along the terrace front on the north (McKenzie, 1969). Hummocky gravel slopes of $39^{\circ}$ had formed where slumps had occurred. Some slopes revealed the ice core. The top of the terrace, at an elevation of about $65 \mathrm{~m}$, sloped toward the inlet at $4^{\circ}$. It was covered with a Dryas mat, several Salix and Alnus, and a lone Populus. The terrace surface was also hummocky with some linear depressions and ridges. The hummocks were generally less than $1 \mathrm{~m}$ high; kettle depressions were as deep as $5 \mathrm{~m}$.

Seismic investigation showed the gravel thickness to average $4.2 \mathrm{~m}(3-6 \mathrm{~m})$; the ice thickness was estimated to be $35 \mathrm{~m}$. The calculated rate of surface lowering, based upon temperature measurements in the kame terrace, was $24 \mathrm{~cm} \mathrm{a}^{-1}$. At that time, the rate of back-wasting of the terrace margin was $6.8 \mathrm{~m} \mathrm{a}^{-1}$.

The mode of collapse of this deposit is by slumping and sliding of gravel along the terrace front and also into depressions on the terrace top, debris flows in gullies, and melt-water erosion and deposition in normally dry alluvial channels and on fans at the terrace front (Fig. 2). Some melt water is released from caves at the base of the buried ice in a process described as stagnant-ice bursts, which are rapid outflows of melt water that carry ice and sediment (McKenzie, 1969).

\section{RECENT OBSERVATIONS}

Additional measurements and observations made on the terrace during the summers of 1977, 1978, 1979, and 1983 showed that it was still ice-cored. The general form of the terrace with a steeply sloping unvegetated front and nearly horizontal top remained, but the terrace margin had retreated. Only one of the early stations established to record the retreat of this face was found in 1977, and a new series was then established (Fig. 3). The surface of the terrace had greater relief, with the deepest depression about $16 \mathrm{~m}$ below the highest hummock. The Dryas mat,

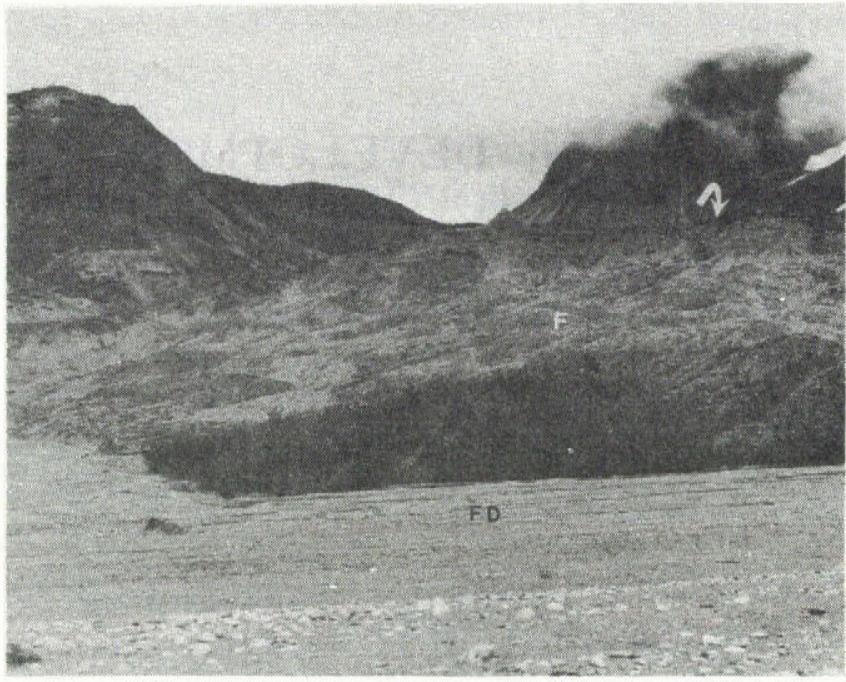

Fig. 2. Kame-terrace front (F) and vegetated top (arrow) showing state of collapse in 1967. The terrace front is ice-cored and continues to subside as indicated by the lack of vegetation except near the fan delta in the foreground. View south-east from the shore of Adams Inlet.

brown where it covered recently slumped gravel, remained, but Salix (1.5 m high), Alnus, and Populus ( $7 \mathrm{~m}$ high) were abundant and several spruce trees, as high as $3.5 \mathrm{~m}$ were found in 1977.

The rate of terrace retreat, now measured over a period of 17 years, has declined. The 1966-67 rate was $6.8 \mathrm{~m} \mathrm{a}^{-1}$ with a summer rate in 1967 that was $1.5-2.2$ times the annual average (Fig. 3). The rates calculated from the 1977-78 measurements average $2.8 \mathrm{~m} \mathrm{a}^{-1}$, and from the 1979-83 measurements the average is $1.9 \mathrm{~m} \mathrm{a}^{-1}$. The 17 year average for terrace retreat is $4.3 \mathrm{~m} \mathrm{a}^{-1}$.

No elevations have been determined since 1967 but, if down-wasting is assumed to have continued at the same rate as the calculated 1967 rate, a diagrammatic profile of retreat away from the shore of Adams Inlet can be constructed as indicated in Figure 4. The reason for the decreased rate is unknown, but it might be due to a thicker gravel cover, more evapo-transpiration, and insulation by an increased amount of vegetation, or decreased through-flow of ground water. A $2.3 \mathrm{~m}$ thick cover of gravel was exposed in the terrace front below stations S-5 and S-6 in 1983. This is less than the average of $4.2 \mathrm{~m}$ measured earlier and the effects of decreased gravel cover should become manifest at the two sites in the near future.

Similar processes and rates of collapse are occurring on another part of the kame terrace about $500 \mathrm{~m}$ to the east and separated from the main part by a gully. Here, a $4 \mathrm{~m}$ wide dry channel headed in a shallow cave in ice in the upper part of the terrace. The cave was in a hummock $4.5 \mathrm{~m}$ high and $6 \mathrm{~m}$ wide, and was the source of the water that cut the channel on the surface, although no channel was visible within the ice of the cave. A stagnant-ice burst similar to that observed in 1967 is thought to be the mechanism that produced the flows necessary to move the medium- to coarse-grained gravel in the channel.

The channel had a flat floor and was unvegetated as was the surrounding field of low hummocks that had formed from terrace collapse. In the hummock over the cave, ice existed under a $30 \mathrm{~cm}$ thick cover of sandy gravel. An ice screw was placed in the ice near the hummock and buried by gravel; the rate of surface lowering over an 8 day period at the end of July 1978 was $1.1 \mathrm{~cm} \mathrm{a}^{-1}$. Thus, the rate of heat flux through the gravel was similar to that measured during the summer of 1967 (McKenzie, 1969). During the 1978 observations the weather was warm with air temperatures as high as $27^{\circ} \mathrm{C}$ under cloudless to hazy skies. By 1978, the $5.5 \mathrm{~m}$ high ice-cored hummock, in which the 1977 cave was located, had completely wasted to produce a topography similar to the surrounding unvegetated low hummocks. The channel remained visible except for one 


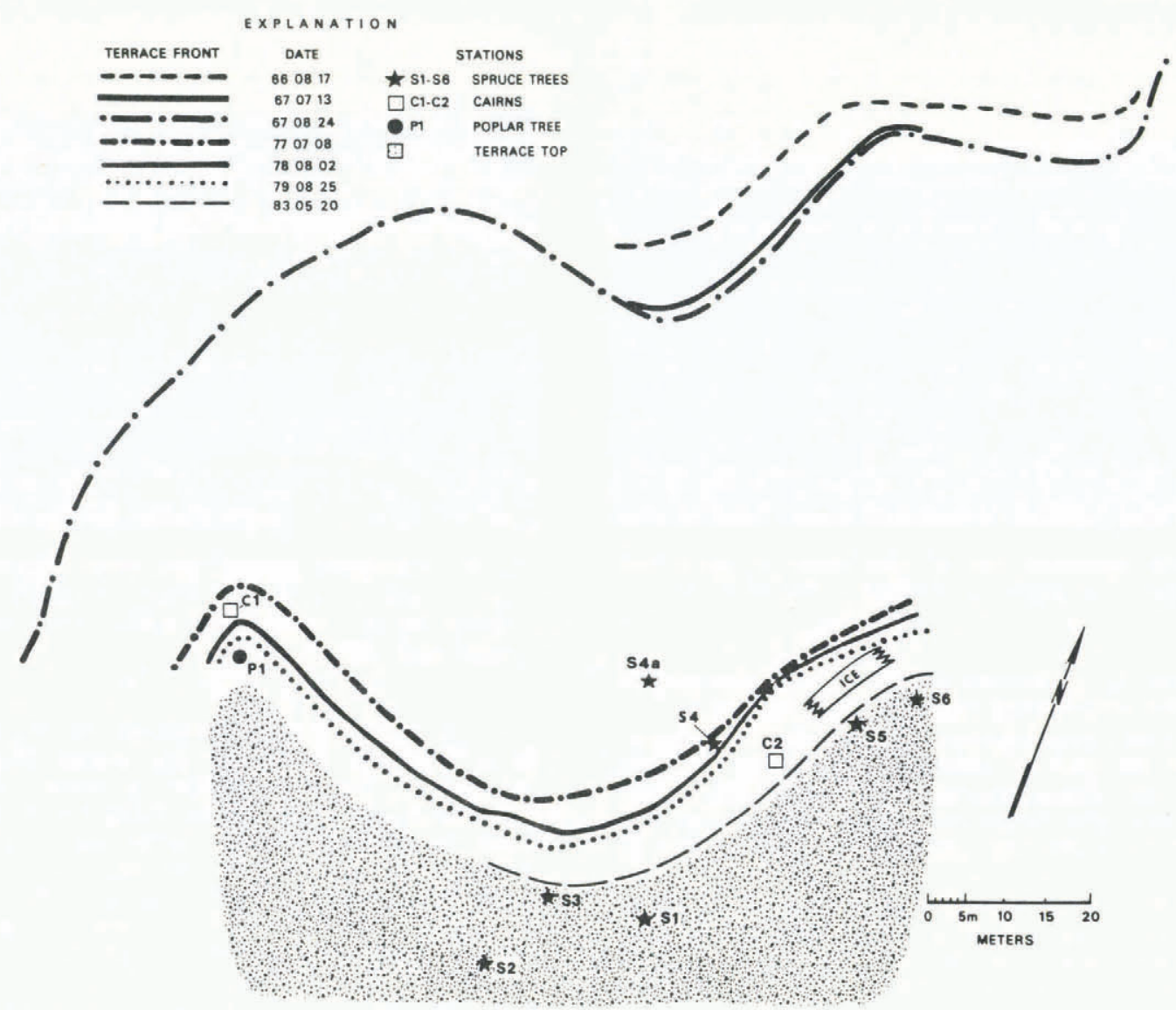

Fig 3. Retreat on the top of the kame-terrace front from 1966 to 1983. The rate from 1966 to 1967 was $6.8 \mathrm{ma}^{-1}$; the rate from 1977 to 1978 was $2.8 \mathrm{~m} \mathrm{a}^{-1}$. From 13 July to 24 August 1967, the margin of the terrace retreated 1.5-2.2 times the annual average rate at that time. Adams Inlet shore is approximately $300 \mathrm{~m}$ north-north-west of the terrace front.

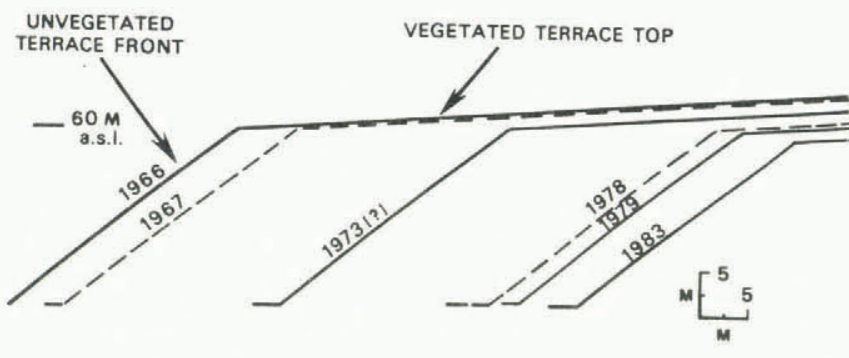

Fig. 4. Diagrammatic retreat of a kame terrace on the south side of Adams Inlet. Shoreline is about $300 \mathrm{~m}$ to the left of the base of the scarp. The top (hummocks are not shown) of each profile was determined from estimated lowering by heat conduction of $24 \mathrm{~cm} \mathrm{a}^{-1}$; the front of each profile was located by measurements of terrace-lip retreat.

area where it was interrupted by a small hill of gravel. This area is thought to be the site of a disappearing or sinking stream, which flowed through a glacier cave and out the other side of the hummock. In some respects, the collapsing kame terrace exhibits karst topography, as described by Clayton (1964).

Observations on another ice-cored kame terrace (Fig. 5) west of the terminus of Casement Glacier (14 km north of the kame described above; Fig. 1) during the summer of 1983 suggest that the pattern of terrace collapse outlined above is a regional one. Sparse vegetation cover and low relief on the terrace surface (Fig. 6) indicate that it is in an early stage of collapse and is comparable to the Adams Inlet kame terrace of 20-30 years ago, except that it formed adjacent to outwash and not a tidal inlet. Above a glacier cave in this kame terrace of Casement Glacier (arrow in Figure 5) a vertical thickness of $11.0 \mathrm{~m}$ of glacier

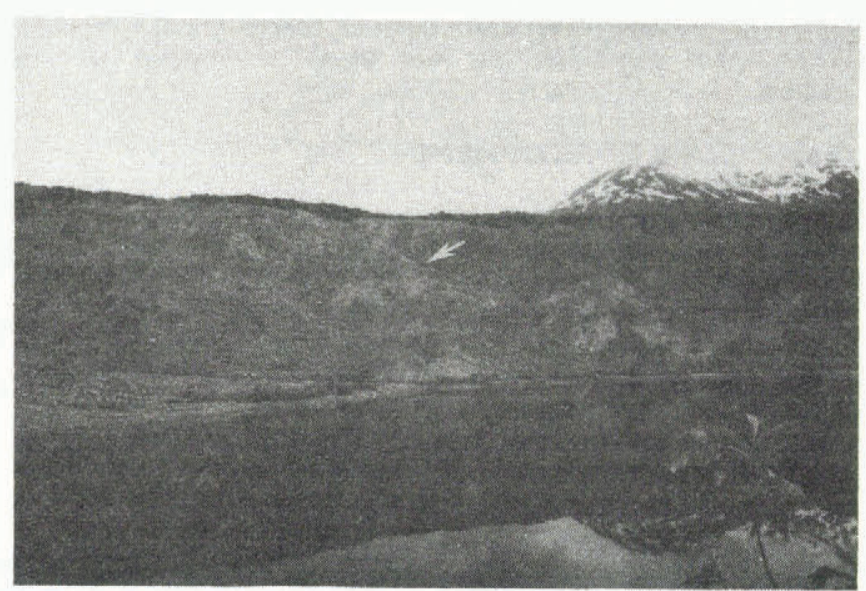

Fig. 5. Kame terrace west of the margin of Casement Glacier. Ice cave at the end of the arrow. Compare with Adams Inlet terrace (Fig. 2).

ice with a surface slope of $34^{\circ}$ is exposed. Covering the ice is a $2.4 \mathrm{~m}$ thick layer of fluvially bedded sand, gravel, and cobbles. Hummocky, non-vegetated sediment can be seen between the kettle lake in the foreground and the cave. The hummocky collapsed surface has an average slope of $16^{\circ}$ toward the lake in the foreground of the figure. Backwasting of the ice-cored slope appears to be the most active ablation process removing buried ice at this site.

The process of sediment collapse redistributes loose incoherent debris. No primary fluvial sedimentary structures survive the slumping, sliding, and debris-flow mechanisms that transport the sediment. Fabric studies on clast 


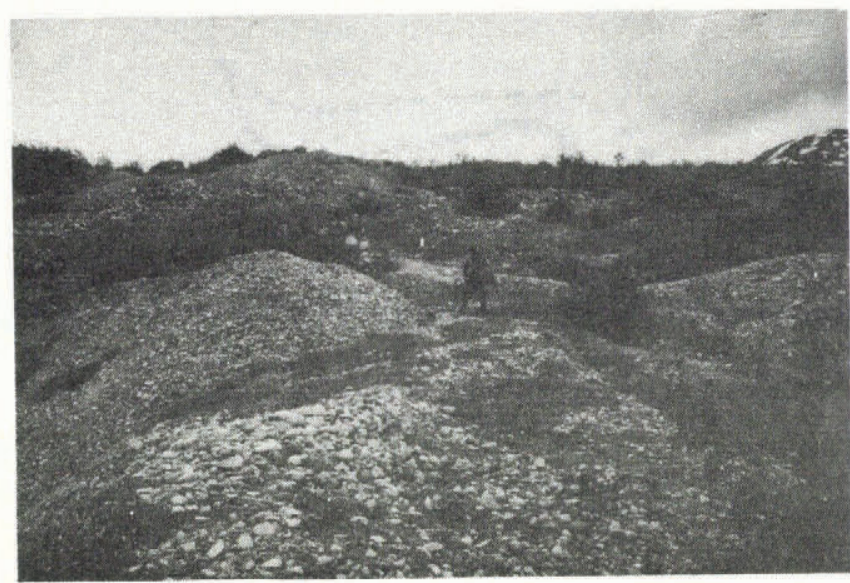

Fig. 6. Partially vegetated top of the kame terrace, near Casement Glacier, in Figure 5. Surface relief is $2-3 \mathrm{~m}$.

orientations were not performed at this site but observations on the nature of redistributed sediment were made.

Gravity-sorted accumulations of cobbles and gravel were found at the base of hummock slopes (Fig. 7). Such accumulations are clast-supported and matrix-free. They occur as lozenge-shaped bodies tens of centimeters thick and $4-5 \mathrm{~m}$ in diameter in low areas between two or more poorly sorted hummocks.

Low arcuate ridges of sand and gravel up to $20 \mathrm{~cm}$ high, $60 \mathrm{~cm}$ wide, and $10-15 \mathrm{~m}$ long were found, one behind the other, parallel to the retreating ice slope. The sediment comprising the ridges was gravity sorted and usually inversely graded. Matrix-free, clast-supported textures characterize the sediments. The preservation potential of the sedimentary textures and fabrics produced by collapse was not determined. During future burial, fines may be washed from adjacent slopes into the interstices of coarse clasts, particularly those in troughs between sediment ridges or hummocks. Pedogenic processes operating after landscape stabilization may also act to produce a fine-grained matrix between surficial coarse-grained deposits. The latter possibility has not been investigated in this region.

\section{FAN-DELTA DEVELOPMENT}

A fan delta lies between the two segments of the kame terrace on the south side of Adams Inlet and shows evidence of partial collapse due to melting ice blocks. The earliest evidence of collapse in this $550 \mathrm{~m}$ wide by $500 \mathrm{~m}$ long fan is a kettle visible on 1948 aerial photographs. By 1966, when first seen in the field, several small kettles existed on the west side. One of these was completely filled as a result of a change in stream position between 1966 and 1967.

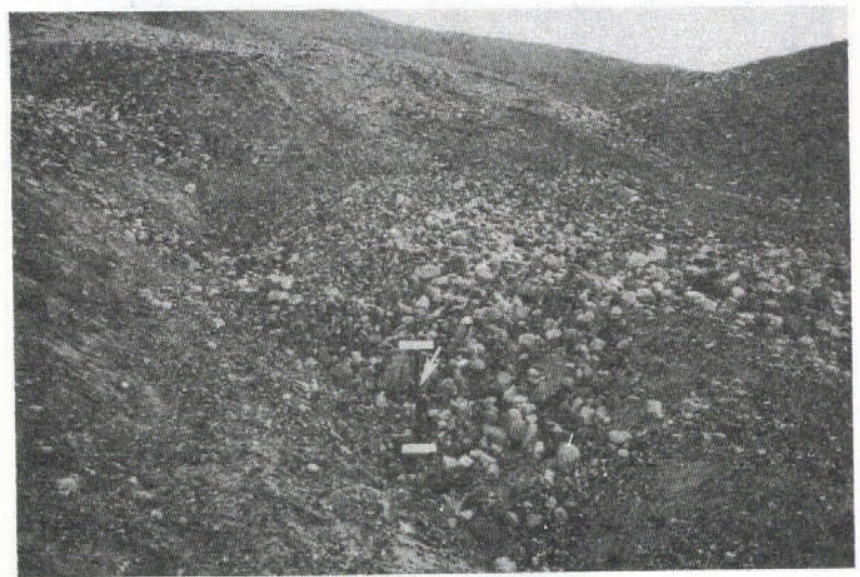

Fig. 7. Arcuate ridge of gravity-sorted gravel and cobbles at the base of the collapsing kame terrace in Figure 5. Arrow points to a $0.5 \mathrm{~m}$ long shovel between the scale lines.

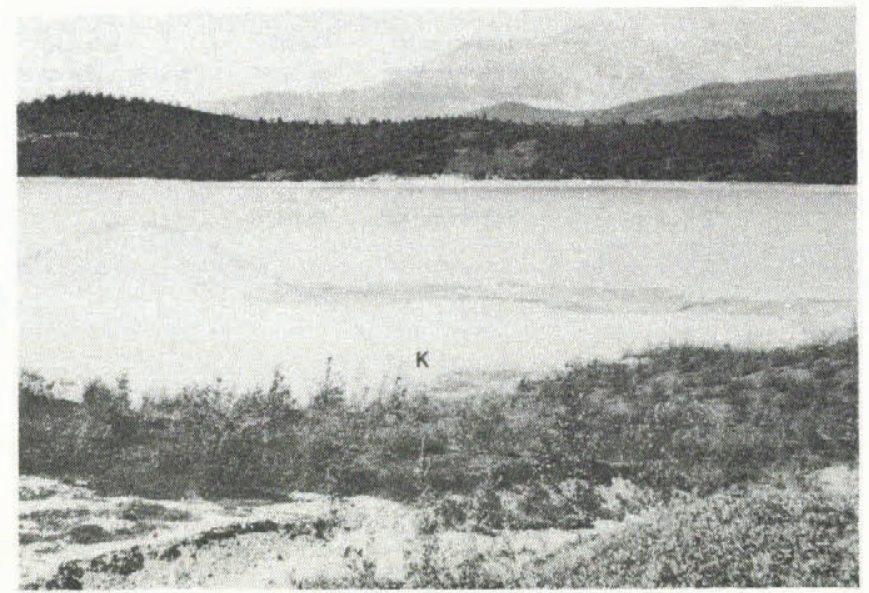

Fig. 8. Collapsed part of fan delta. Kettle (K) is filled by the sea at high tide. Trees, originally on a vegetated higher terrace of the fan delta, were as much as $5 \mathrm{~m}$ below high tide in 1977.

The major collapse feature on the fan delta is a kettle in a vegetated terrace of the eastern third of the fan, adjacent to the kame terrace. A terrace remnant protects this area from further fluvial filling by the active fan delta. Over the past decade the kettle has expanded to include parts of the kame terrace and the delta front, so that the kettle is filled by the sea at high tide (Fig. 8).

1977, 1978, and $197935 \mathrm{~mm}$ photographs document changes here. At low tide during the 1977 field season, sections of 14 drowned trees and one live tree were collected and their elevations in the kettle recorded. The trees represented two species, Salix alaxensis and Salix sitchensis, and had annuli that suggested a range in ages from 7 to 16 years. The 16 year old tree was live on the terrace just above sea-level. A good correlation between apparent age and depth below sea-level could not be established, possibly because of sliding of parts of the ground cover. The suggested collapse rate is $0.5 \mathrm{~m} \mathrm{a}^{-1}$, which is on the same order as the vertical rates for the kame terrace. The depth to the ice and its thickness are not known.

Adams Inlet continues to receive large amounts of glacial melt water and inwash of sediment from surrounding slopes. Accumulation rates, for coarse sediments only, have been estimated at $1.14 \times 10^{6}$ tonnes $^{-1}$ for one fan delta (McKenzie and Goodwin, 1980), but no mass-balance studies of suspended sediment flux into and out of the inlet have been made. The existence of extensive silty tidal flats below mean high-tide level suggests that most of the glacially derived fines transported to the inlet remain there. Laminated silt is filling the kettle in the small fan delta described above, even as it collapses. A large lens- or discshaped deposit of laminated silt, covering outwash gravels and terrestrial vegetation, and disturbed by ring-shaped normal faults will ultimately result. Renewed progradation of a fan-delta system at this site would bury the fines in coarse sands and gravels.

\section{SUMMARY AND SUGGESTIONS FOR FURTHER RESEARCH}

During the Neoglacial maximum, Adams Inlet Glacier was $760 \mathrm{~m}$ above sea-level. Ablation of the glacier and its remnants produced a glacier-free Adams Inlet by 1946. Buried ice continues to melt and modify the topography. Although many examples of collapsed and collapsing glacial deposits occur in Adams Inlet, only two adjacent features on the south side of the inlet were the subjects of longterm studies. These were selected because of the observational record and the observed stagnant-ice burst in one of them.

Changes in the kame terrace are due to slumping, sliding, debris flows, and fluvial action, sometimes associated with stagnant-ice bursts from caves in the buried ice blocks. The calculated rate of surface lowering is about $0.25 \mathrm{~cm} \mathrm{a}^{-1}$; back-wasting has averaged $4.3 \mathrm{~m} \mathrm{a}^{-1}$ between 
1966 and 1983, and has decreased from $6.8 \mathrm{~m} \mathrm{a}^{-1}$ to $1.9 \mathrm{~m} \mathrm{a}^{-1}$ in that period. A fan delta has built into the sea and against the margin of a vegetated part of the kame terrace. The rate of collapse of one kettle in this fan delta has been estimated from biological evidence to be about $0.5 \mathrm{~m} \mathrm{a}^{-1}$

Monitoring of changes in these collapsing land forms should continue in order to establish variations in rates of collapse and the nature of the post-collapse topography. Earlier stages in the history of these collapsing deposits can be observed at other sites within Glacier Bay National Park and Preserve such as at nearby Casement Glacier or Burroughs Glacier Remnant. The destruction of vegetation on these ice-cored features and the ecological succession following stabilization of the substrate should also be considered for study. Lastly, investigations into the texture, fabric, and stratigraphy of sediment bodies produced by collapse should be made. Recognition of ice-collapsed sediments from the geologic record would be facilitated by such studies. Studies.

This is contribution C-573 of the Institute of Polar

\section{REFERENCES}

Clayton, L. 1964. Karst topography on stagnant glaciers. Journal of Glaciology, Vol. 5, No. 37, p. 107-12.

Field, W.O., jr. 1947. Glacier recession in Muir Inlet, Glacier Bay, Alaska. Geographical Review, Vol. 37, No. 3, p. $369-99$.

Field, W.O., jr. 1964. Observations of glacier variations in Glacier Bay, southeastern Alaska, 1958 and 1961. Preliminary report. New York, American Geographical Society.

Goldthwait, R.P. 1963. Dating the Little Ice Age in Glacier Bay, Alaska. International Geological Congress, 21st Session, Norden, 1960, Pt. 27, p. 37-46.
Goldthwait, R.P., and others. 1966. Soil development and ecological succession in a deglaciated area of Muir Inlet, southeast Alaska, by R.P. Goldthwait [and 8 others]. Ohio State University. Institute of Polar Studies. Report No. 20.

Goodwin, R.G., and Brookner, P.L. 1985. Landforms and lithofacies produced by wastage of the Casement Glacier, Glacier Bay, Alaska. Geological Society of America. Abstracts with Programs, Vol. 17, No. 5, p. 290.

Haselton, G.M. 1966. Glacial geology of Muir Inlet, southeast Alaska. Ohio State University. Institute of Polar Studies. Report No. 18.

McKenzie, G.D. 1969. Observations on a collapsing kame terrace in Glacier Bay National Monument, south-eastern Alaska. Journal of Glaciology, Vol. 8, No. 54, p. 413-25.

McKenzie, G.D. 1970. Glacial geology of Adams Inlet, southeastern Alaska. Ohio State University. Institute of Polar Studies, Report No. 25.

McKenzie, G.D., and Goldthwait, R.P. 1971. Glacial history of the last eleven thousand years in Adams Inlet, southeastern Alaska. Geological Society of America. Bulletin, Vol. 82, No. 7, p. 1767-82.

McKenzie, G.D., and Goodwin, R.G. 1980. Delta growth in a marine inlet. Geological Society of America. Abstracts with Programs, Vol. 12, No. 5, p. 250.

MacKevett, E.M., jr, and others. 1971. Mineral resources of Glacier Bay National Monument, Alaska, by E.M. MacKevett, $j r$, D.A. Brew, C.C. Hawley, L.C. Huff, and J.G. Smith. U.S. Geological Survey. Professional Paper 632.

Muir, J. 1915. Travels in Alaska. Boston and New York, Houghton Mifflin Co.

Price, R.J. 1966. Eskers near the Casement Glacier, Alaska. Geografiska Annaler, Vol. 48A, No. 3, p. 111-25.

Reid, H.F. 1892. Studies of Muir Glacier, Alaska. National Geographic Magazine, Vol. 4, p. 19-84.

Reid, H.F. 1896. Glacier Bay and its glaciers. U.S. Geological Survey. Annual Report, 16th [for the year] 1894-95, Pt. I, p. 415-61. 